\title{
Role of Light in the Synthesis of Nitrate Reductase and Nitrite Reductase in Rice Seedlings
}

\author{
By S. K. SAWHNEY and M. S. NAIK \\ Division of Biochemistry, Indian Agricultural Research Institute, \\ New Delhi 12, India
}

(Received 2 June 1972)

\begin{abstract}
1. In rice seedlings synthesis of methyl viologen-nitrite reductase was stimulated by light, as was that of NADH-nitrate oxidoreductase (EC 1.6.6.1). A small residual effect of light on the synthesis of the enzymes persisted in the dark for a short time. 2. In etiolated seedlings exposed to light and nitrate, a lag period of $3 \mathrm{~h}$ was necessary before enzyme synthesis commenced, whereas in green seedlings kept in the dark for $36 \mathrm{~h}$, synthesis of both the enzymes started as soon as light and nitrate were provided. 3. Experiments with cycloheximide suggested that fresh protein synthesis in light was necessary for formation of active enzymes. Mere activation by light of inactive enzymes or their precursors, was not involved. 4. In green seedlings synthesis of nitrite reductase was more sensitive to chloramphenicol than that of nitrate reductase. In chloramphenicol-treated etiolated seedlings, however, synthesis of both the enzymes was inhibited to the same extent on subsequent light-treatment. 5 . A close correlation was observed between inhibition of the Hill reaction by 3-(3,4-dichlorophenyl)-1,1-dimethylurea and simazin [2-chloro-4,6bis(ethylamino)-s-triazine] (at high concentration) and the inhibition of enzyme synthesis. At lower concentrations, however, simazin stimulated nitrate reductase. 6 . In a single leaf synthesis of enzymes was observed only in portions exposed to light, whereas little activity was present in the dark covered part. 7. $\mathrm{CO}_{2}$ deprivation severely inhibited the synthesis of enzymes in the light. Sucrose could not reverse this effect. 8. In excised embryos cultured in synthetic media containing sucrose, light was also essential for enzyme formation. 9. It is suggested that redox changes taking place in the green tissues as a result of the Hill reaction create conditions favourable for the induced synthesis of nitrate reductase and nitrite reductase.
\end{abstract}

Light is an important factor controlling the induced synthesis of nitrate reductase (EC 1.6.6.1) in green plants (Hageman \& Flesher, 1960; Shibata et al., 1969). Nitrite reductase, which catalyses the next step in the assimilation of nitrate into ammonia, has been reported to be dependent for its activity on reductants generated in the light reaction of photosynthesis (Ramirez et al., 1966), but the role of light, if any, in the synthesis of the enzyme itself is not known.

As regards the possible mechanism of the action of light in the induction process of nitrate reductase, Travis et al. (1970a) and Travis \& Key (1971) suggested that the presence of a higher proportion of polyribosomes in illuminated seedlings than in etiolated ones, was responsible. Lips \& Roth-Bejerano (1969) and Roth-Bejerano \& Lips (1970), however, reported that in tobacco leaves the requirement for light for induction of the enzyme could be replaced by supplying appropriate concentrations of gibberellic acid and kinetin in the dark. Kanangara \& Woolhouse (1967) found that in addition to light and nitrate, the presence of $\mathrm{CO}_{2}$ was also necessary for the formation of nitrate reductase. Sawhney et al. (1972), using ethyl methanesulphonate-induced chlorophyll mutants of barley, suggested a possible role of the light-reaction of photosynthesis in creating conditions favourable for the synthesis of the enzyme. In the present paper we report that in rice seedlings synthesis of nitrite reductase is also stimulated by light. It is shown that a variety of factors such as inhibitors of photosystem II, $\mathrm{CO}_{2}$ deprivation or partial exposure of leaves, which inhibit the Hill reaction as well, markedly retard the synthesis of nitrate reductase and nitrite reductase in green tissues. However, in illuminated plants a small residual effect of light was also found to persist for a short time after they were transferred to the dark. A preliminary report has been presented (Sawhney \& Naik, 1972).

\section{Materials and Methods}

Seeds of rice (Oryza sativa), variety Taichung Native I, were used. The seedlings were raised in 
well-washed quartz sand either in circular plastic pots $(20 \mathrm{~cm}$ diam. $\times 7 \mathrm{~cm}$ deep $)$ or petri plates $(10 \mathrm{~cm} \times$ $1.7 \mathrm{~cm})$ placed in a wooden chamber, thermostatically maintained at $30 \pm 2^{\circ} \mathrm{C}$ and illuminated with a bank of four $40 \mathrm{~W}$ fluorescent tubes, each $120 \mathrm{~cm}$ long fixed about $20 \mathrm{~cm}$ above the seedlings. This arrangement provided a light-intensity of about $1000 \mathrm{ft}$-candle (10764 lx) at the level of the leaves. For dark treatment, the seedlings were kept in an incubator maintained at $30^{\circ} \mathrm{C}$.

The seedlings were irrigated with glass-distilled water until they had grown sufficiently for experimentation. The enzymes were induced by providing them with Hoagland nutrient solution (Hewitt, 1952) with slight modifications. Nitrogen was supplied exclusively as nitrate salts of potassium and calcium, and $\mathrm{NH}_{4} \mathrm{H}_{2} \mathrm{PO}_{4}$ was replaced by $\mathrm{KH}_{2} \mathrm{PO}_{4}$ to provide an equal amount of phosphate. To each plastic pot or petri plate $100 \mathrm{ml}$ or $20 \mathrm{ml}$ of nutrient solution, respectively, was added. This was changed after every $12 \mathrm{~h}$.

\section{Application of inhibitors}

Aqueous solutions of inhibitors of protein synthesis (chloramphenicol and cycloheximide) were supplied to the plants $4 \mathrm{~h}$ before nitrate or light was provided. They were added to the Hoagland solution. Inhibitors of photosystem II, simazin [2-chloro-4,6bis(ethylamino)-s-triazine] and 3-(3,4-dichlorophenyl)-1,1-dimethylurea were added in the Hoagland solution and also as foliar sprays. Aqueous solutions of the inhibitors prepared in $0.1 \%$ Tween were sprinkled on the seedlings as a fine mist every $6 \mathrm{~h}$ by using an atomizer. The control seedlings were sprayed with Tween solution without the inhibitor.

\section{Extraction and assay of enzymes}

The seedlings were cut at the stem-base and washed thoroughly with water. Plant material (1g) was macerated in $4 \mathrm{ml}$ of $0.1 \mathrm{M}$-potassium phosphate buffer (pH 7.5) containing 1 mM-cysteine in a mortar and pestle. The brei was centrifuged at $10000 \mathrm{~g}$ for $20 \mathrm{~min}$ and the supernatant used as the enzyme preparation. All the operations were carried out at $0-4^{\circ} \mathrm{C}$.

Nitrate reductase was assayed by the method of Hageman \& Flesher (1960). The reaction mixture in the final volume of $2 \mathrm{ml}$ contained, in $\mu \mathrm{mol}$ : phosphate buffer, $\mathrm{pH} 7.5,100 ; \mathrm{KNO}_{3}, 20 ; \mathrm{NADH}, 0.68$; and $0.2 \mathrm{ml}$ of enzyme preparation. In blank tubes, NADH was omitted. The reaction was stopped after $20 \mathrm{~min}$ incubation at $30^{\circ} \mathrm{C}$ by adding $0.1 \mathrm{ml}$ of $1 \mathrm{M}$-zinc acetate and $1.9 \mathrm{ml}$ of $70 \%(\mathrm{v} / \mathrm{v})$ ethanol. The contents were centrifuged at $3000 \mathrm{~g}$ for $10 \mathrm{~min}$ and the nitrite formed was determined in a suitable sample of the supernatant by adding $1 \mathrm{ml}$ of a $1 \%(\mathrm{w} / \mathrm{v})$ solution of sulphanilamide prepared in $1 \mathrm{M}-\mathrm{HCl}$ and $1 \mathrm{ml}$ of a $0.02 \%(\mathrm{w} / \mathrm{v})$ solution of $N$-1-naphthylethylenediamine dihydrochloride. The $E_{540}$ was measured after $20 \mathrm{~min}$ in a Spectronic 20 spectrophotometer. One unit of nitrate reductase activity denotes $1 \mu \mathrm{mol}$ of $\mathrm{NO}_{2}{ }^{-}$formed/20min per $\mathrm{g}$ of tissue.

Nitrite reductase activity was determined by the method of Joy \& Hageman (1966) with slight modifications. The assay was done in tubes $(1 \mathrm{~cm} \times$ $7.5 \mathrm{~cm}$ ) with a thin layer of paraffin over the reaction mixture to prevent rapid oxidation of chemically reduced Methyl Viologen, instead of in bottles stoppered with rubber serum caps. The reaction mixture (final volume $2 \mathrm{ml}$ ) contained, in $\mu \mathrm{mol}$ : potassium phosphate buffer, pH7.5, 100; $\mathrm{NaNO}_{2}$, 1.5; Methyl Viologen, 0.6 ; and $0.2-0.3 \mathrm{ml}$ of enzyme preparation. A thin film of liquid paraffin was layered on the surface of the reaction mixture. The reaction was started by pipetting $7.5 \mu \mathrm{mol}$ of $\mathrm{Na}_{2} \mathrm{~S}_{2} \mathrm{O}_{4}$ below the paraffin layer. The contents were gently stirred with a fine sealed capillary tube to ensure uniform distribution of the reduced dye. The reaction was stopped after $20 \mathrm{~min}$ incubation at $30^{\circ} \mathrm{C}$ by vigorously shaking the contents till Methyl Viologen was completely oxidized. Tubes containing boiled plant extracts served as controls. Residual nitrite was determined in $0.1 \mathrm{ml}$ samples. Disappearance of nitrite was taken as a measure of nitrite reductase activity, and one unit of nitrite reductase activity represents $1 \mu \mathrm{mol}$ of $\mathrm{NO}_{2}{ }^{-}$reduced/20 min per $\mathrm{g}$ of tissue.

\section{Isolation of chloroplasts and determination of Hill activity}

Chloroplasts were isolated from the healthy leaves of rice seedlings in $0.067 \mathrm{M}$-potassium phosphate buffer, pH7.3, containing $0.5 \mathrm{M}$-sucrose and $0.01 \mathrm{M}$ $\mathrm{KCl}$ as described by Gorham (1955). The chloroplasts were washed twice in the extraction buffer and finally suspended in $0.02 \mathrm{M}$-potassium phosphate buffer, pH6.5, containing $0.05 \% \mathrm{KCl}$. The Hill activity of the isolated chloroplasts was measured by the rate of photoreduction of dichlorophenol-indophenol as described by Vishniac (1957). The reaction mixture (final volume $3 \mathrm{ml}$ ) contained in $\mu \mathrm{mol}$ : potassium phosphate buffer, $\mathrm{pH} 6.5,110 ; \mathrm{KCl}, 40$; dichlorophenol-indophenol, 0.3 ; chloroplast preparation containing about $20 \mu \mathrm{g}$ of chlorophyll. The tubes were illuminated at saturating light-intensity in the water bath of an illuminated Warburg apparatus maintained at $25^{\circ} \mathrm{C}$. The decrease in $E_{610}$ after $45 \mathrm{~s}$ was immediately measured with a Spectronic 20 instrument. Tubes kept in complete darkness served as controls. The Hill activity was calculated as $\mu \mathrm{mol}$ of dichlorophenol-indophenol reduced/ $5 \mathrm{~min}$ per $\mathrm{mg}$ of chlorophyll. Chlorophyll content of 
the preparation was determined by the method of Arnon (1949) after extraction with aq. $80 \%(v / v)$ acetone.

\section{Determination of protein}

Protein content of the plant extract was determined by the method of Lowry et al. (1951) after precipitation with $5 \%(\mathrm{w} / \mathrm{v})$ trichloroacetic acid with bovine serum albumin as standard.

\section{Embryo culture}

Healthy seeds were selected, dehusked, surfacesterilized with $0.01 \% \mathrm{HgCl}_{2}$ for $7 \mathrm{~min}$ and then transferred to sterilized petri plates on two layers of moist filter paper. After $24 \mathrm{~h}$ the embryos, which had just started developing, were removed and transferred to tubes $(2.5 \mathrm{~cm} \times 15 \mathrm{~cm})$ containing $10 \mathrm{ml}$ of glycine-free White's nutrient medium (Street \& Henshaw, 1966) solidified with $1 \%$ agar. One set of seedlings was kept under continuous illumination whereas the other set was in darkness.

\section{Results}

\section{Time-course of induction}

Fig. 1 shows that after addition of nitrate to illuminated seedlings, the nitrate reductase activity progressively increased up to $12 \mathrm{~h}$, whereas in the absence of light there was hardly any synthesis. Seedlings grown in the light before addition of nitrate and then transferred to darkness also synthesized the enzyme at a slow rate up to $12 \mathrm{~h}$, after which a steady decline was observed. Thus a small residual effect of light persisted in the dark for a short time. Synthesis of nitrate reductase in the dark for a brief period owing to prior light exposure has also been reported by Beevers et al. (1965), Chen \& Ries (1969) and Travis et al. (1970b).

Nitrite reductase activity showed almost the same trend, except that the decline in enzyme activity after $12 \mathrm{~h}$ dark treatment was less pronounced. This may be because this enzyme is more stable in vivo than nitrate reductase (Schrader et al., 1968).

The role of photosynthetic reactions in the synthesis of the enzymes is evident from Fig. 2 also. In completely etiolated seedlings, after exposure to light and nitrate, a time-lag of $3 \mathrm{~h}$ was necessary before the synthesis of both the enzymes could commence. This lag period was not required in continuously illuminated seedlings, as well as in green plants which remained in the dark for $36 \mathrm{~h}$ before exposure to light and nitrate. With the latter treatment the rate of nitrate reductase synthesis was almost the same as

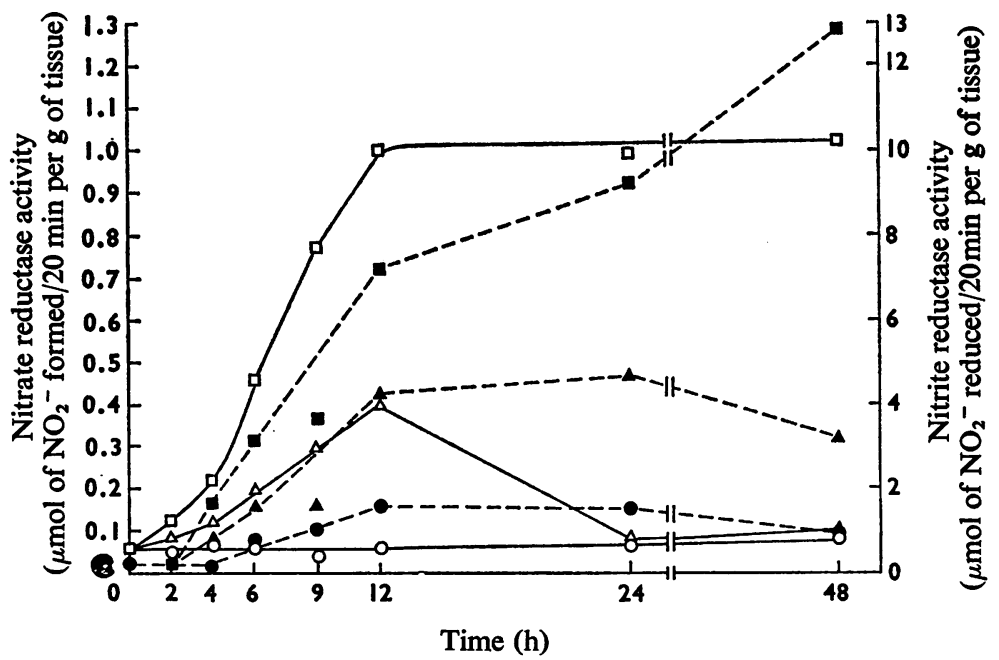

Fig. 1. Time-course of induction of nitrate reductase and nitrite reductase activities in the shoot system of rice seedlings under different light treatments

Two sets of rice seedlings were grown in plastic pots in the light, whereas the third set was kept in a dark chamber $(O$ and $\bullet)$. After 14 days all the seedlings were provided with Hoagland solution containing nitrate and one of the sets grown in the light was immediately transferred to the dark $(\Delta$ and $\Delta$ ), whereas the other was allowed to remain in the light ( $\square$ and $\square$ ). Nitrate reductase $(0, \Delta, \square)$ and nitrite reductase $(\bullet, \Delta, \square)$ activities were assayed by the procedures described in the Materials and Methods section. 


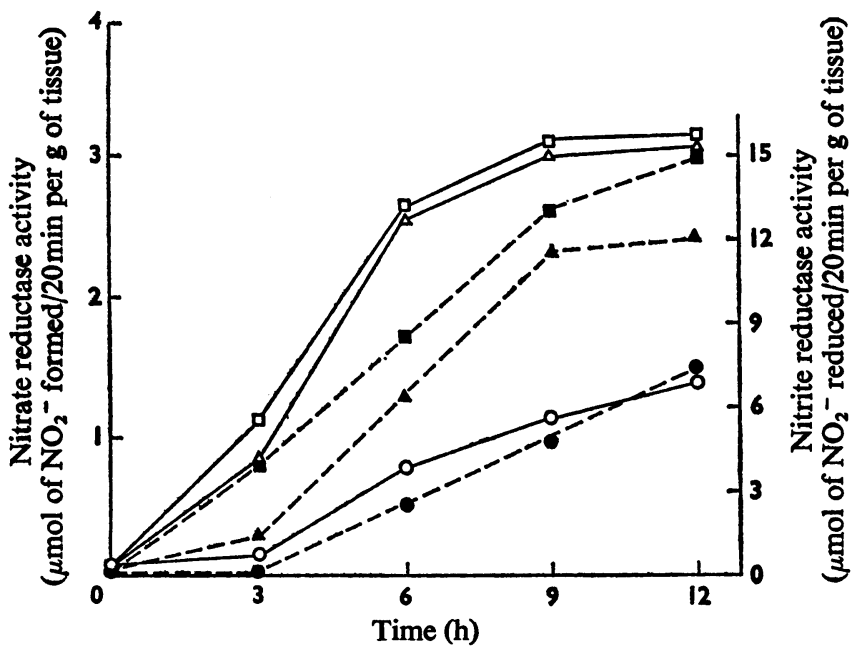

Fig. 2. Time-course of synthesis of nitrate reductase and nitrite reductase in the shoot system of rice seedlings under different light treatments

The seedlings were grown either in continuous light or in complete darkness ( 0 and $\bullet$ ). On the 14th day one set of seedlings growing in the light was transferred to darkness $(\Delta$ and $\Delta)$, whereas the other was allowed to remain in the light ( $\square$ and $\square$ ). Then $48 \mathrm{~h}$ later all the sets were provided with Hoagland solution containing nitrate and immediately transferred to the light. Nitrate reductase $(0, \Delta, \square)$ and nitrite reductase $(\bullet, \Delta, \boldsymbol{\square})$ activities were determined at the time-intervals specified in the figure by the procedures outlined in the Materials and Methods section.

in continuously illuminated plants, but nitrite reductase synthesis was slightly slower. The residual effect of previous exposure to light was perceptible only up to $12 \mathrm{~h}$ (see Fig. 1), and hence after $36 \mathrm{~h}$ of dark treatment it obviously had no role to play in the synthesis of the enzymes on addition of nitrate. The only difference between the completely etiolated seedlings and the green ones kept in the dark for $36 \mathrm{~h}$ was that in the latter the photosynthetic apparatus was already present and could start functioning as soon as light was available. In the former, a lag period was necessary for its development.

\section{Effect of cycloheximide}

The main objective of these experiments was to find whether the enzymes are activated or induced by light. Preliminary experiments showed that at the concentration used $(6 \mu \mathrm{g} / \mathrm{ml})$ the antibiotic inhibited synthesis of both the enzymes by about $50 \%$ when nitrate was supplied to green seedlings. Results in Fig. 3 show that addition of nitrate to etiolated plants in the dark before cycloheximide treatment did not prevent the effect of the inhibitor, and about $60 \%$ inhibition of both the enzymes was still observed when the seedlings were transferred to light. Although cycloheximide has little effect on chloroplast protein synthesis (Kirk, 1970), it is likely to inhibit the development of chloroplasts in etiolated seedlings by blocking the synthesis of structural proteins (Smillie et al., 1967; Gibbons et al., 1969). Hence the effect of cycloheximide as well as of addition of nitrate in the dark was also studied in green seedlings with fully developed chloroplasts (Fig. 4). Again, nitrate reductase activity in cycloheximide-treated seedlings was only about $50 \%$ of the control, thus suggesting that the enzyme or its inactive precursor is not formed in the dark even in the presence of the inducer. If the latter had been synthesized in darkness, it could very well have been activated in light even in the presence of cycloheximide, when further protein synthesis is blocked. The results therefore indicate that fresh protein synthesis is essential for the formation of nitrate reductase in the light. Moreover, in seedlings provided with nitrate in the dark for different time-intervals before exposure to light, the timecourse of subsequent induction of nitrate reductase was almost identical with that observed when the inducer and light were provided simultaneously (Fig. 4). This again suggests that the process of induction starts only when light is available and that 


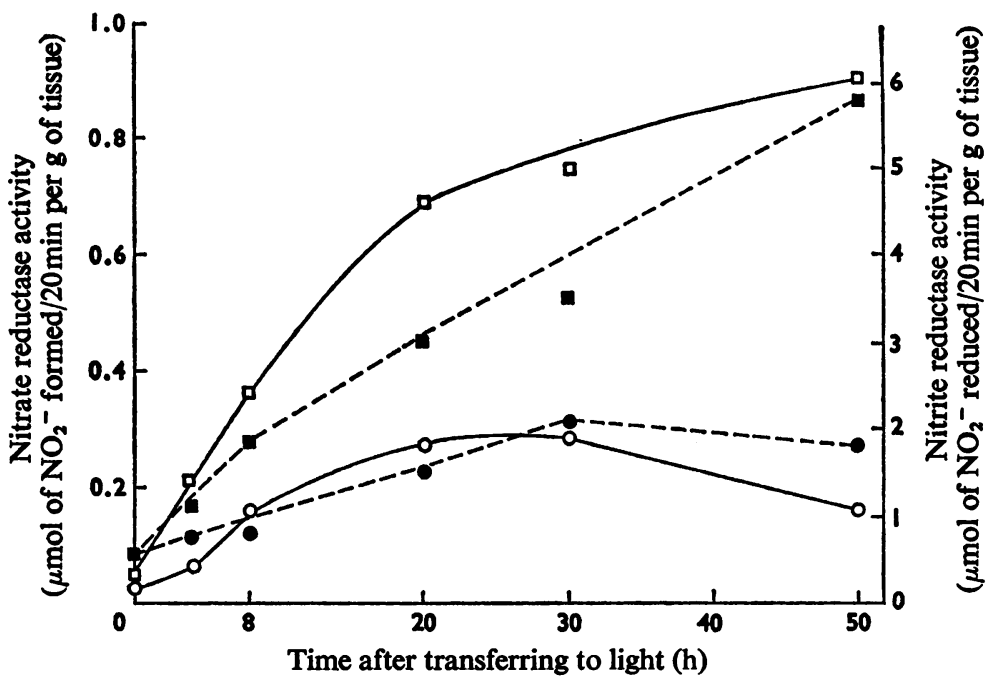

Fig. 3. Induction of nitrate reductase and nitrite reductase activities in etiolated seedlings transferred to light in the presence of cycloheximide

Two sets of rice seedlings were grown in petri plates in the dark chamber. On the 15 th day the seedlings were provided with Hoagland solution containing nitrate. After $12 \mathrm{~h}$ nutrient solution containing $6 \mu \mathrm{g}$ of cycloheximide $/ \mathrm{ml}$ was added to one set of the seedlings, and $4 \mathrm{~h}$ later both the sets of the seedlings were transferred to the light. Activities of nitrate reductase $(0, \square)$ and nitrite reductase $(\bullet, \square)$ were determined at the specified time-intervals by the procedures described in the Materials and Methods section. Control seedlings ( $\square$ and $\square$ ); cycloheximide-treated seedlings ( 0 and $\bullet$ ).

inactive enzyme or enzyme precursors are not synthesized in the dark.

\section{Effect of chloramphenicol}

This antibiotic is known to inhibit protein synthesis in subcellular organelles of plant tissues, but cytoplasmic protein synthesis is relatively insensitive (Glasziou, 1969; Boulter, 1970; Kirk, 1970). Results in Table 1 show that chloramphenicol at $3 \mathrm{mg} / \mathrm{ml}$ inhibited the synthesis of nitrate reductase and nitrite reductase by $\mathbf{4 0}$ and $\mathbf{9 0} \%$ respectively in green seedlings. However, when etiolated seedlings were treated with the antibiotic in the dark, synthesis of nitrate reductase was inhibited by $90 \%$ after subsequent transfer to light. Since chloramphenicol is a very effective inhibitor of chloroplast protein synthesis, treatment of etiolated seedlings with chloramphenicol would obviously retard the development of photosynthetic capability even after illumination. This again suggests a close link between synthesis of nitrate reductase and photoreactions. Schrader et al. (1967) observed that synthesis of nitrite reductase is much more sensitive than that of nitrate reductase to chloramphenicol, and hence concluded that the former enzyme is located in chloroplasts. Our results also indicate that chloramphenicol in- hibited synthesis of nitrite reductase to a much greater extent than that of nitrate reductase in green seedlings. However, in etiolated seedlings, subsequently exposed to light, both the enzymes were inhibited to the same extent.

Chloramphenicol is known to be a selective inhibitor of $70 \mathrm{~S}$ ribosome protein synthesis when used at low concentrations. The internal concentration of the antibiotic in shoots of rice seedlings in the above experiment is not known but it is probably much lower than the $3 \mathrm{mg} / \mathrm{ml}$ added to the nutrient solution. Secondary effects of a high concentration of chloramphenicol, such as those on oxidative phosphorylation, cannot be completely ruled out, but comparison of the results of the chloramphenicoltreated seedlings continuously kept in the light and those treated with the antibiotic in the dark clearly show that inhibition of development of functional chloroplasts in the latter was responsible for the retardation of the synthesis of both the enzymes.

\section{Role of the Hill reaction}

Chloroplasts prepared from seedlings treated with different concentrations of 3-(3,4-dichlorophenyl)1,1-dimethylurea and simazin, two specific inhibitors of photosystem II (Bishop, 1962), were examined for

Vol. 130 


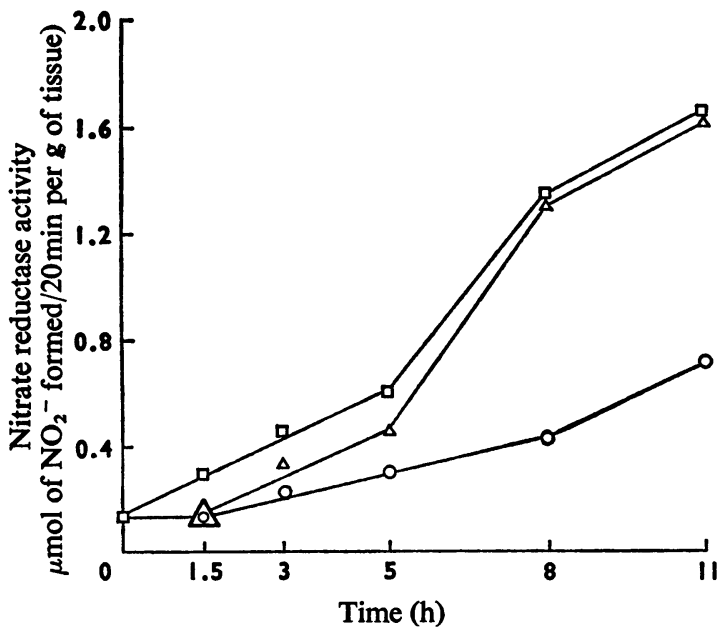

Fig. 4. Time-course of induction of nitrate reductase activity in rice seedlings provided with inducer at different periods in the dark

After 13 days of growth in the light, two pots were removed to a dark chamber. Then $48 \mathrm{~h}$ after transfer to darkness, the seedlings were provided with Hoagland solution $16 \mathrm{~h}$ before they were exposed to light again $(\Delta)$. To one of these pots kept in the dark chamber, a nutrient solution containing $6 \mu \mathrm{g}$ of cycloheximide $/ \mathrm{ml}$ was added $4 \mathrm{~h}$ before transferring it to light (o). A set of seedlings which had been grown in continuous light ( $\square$ ) was provided with the nutrient solution when the other seedlings were transferred to the light. Activity of nitrate reductase was determined at specified time-intervals after transferring the seedlings kept in darkness to the light. inhibition of Hill activity. Nitrate reductase and nitrite reductase activities were also assayed in extracts of the seedlings prepared separately. The results in Table 2 show a close correlation between inhibition of Hill activity by 3-(3,4-dichlorophenyl)1,1-dimethylurea and inhibition of the synthesis of both the enzymes. Simazin also showed the same effect at $1 \mu \mathrm{g} / \mathrm{ml}$. At lower concentrations of the herbicide, however, although Hill activity was partially blocked, this was not accompanied by decreased synthesis of nitrate reductase. In fact at $0.25 \mu \mathrm{g} / \mathrm{ml}$ a slight stimulation of the enzyme was observed. Tweedy \& Ries (1967), Ries et al. (1967) and Singh \& Salunkhe (1970) also found that seedlings treated with sub-lethal concentrations of simazin showed higher nitrate reductase activity. Information about the exact mechanism of the stimulatory effect of a variety of herbicides at low concentrations on nitrate reductase is not available. Beevers et al. (1963) suggested that stimulation in nitrate reductase activity by 2,4-dichlorophenoxyacetic acid in corn could be due to intramolecular changes in thiol groups of the protein leading to structural modifications of the protein molecule which might result in enhanced activity. Singh \& Salunkhe (1970) have extended the same suggestion for the stimulatory effect of various s-triazines, including simazin, on nitrate reductase activity. However, we failed to observe any stimulation of the enzyme activity in vitro on addition of simazin over a range of $0.125-1.25 \mu \mathrm{M}$.

\section{Effect of different light regimes}

The influence of light of different wavelengths on induction of the enzymes was studied by using coloured cellophan papers as filters. The thickness of

\section{Table 1. Effect of chloramphenicol on synthesis of nitrate reductase and nitrite reductase in rice seedlings}

Rice seedlings were raised in Petri plates either in continuous light or complete darkness. At 10 days after germination some of the seedlings were supplied with $3 \mathrm{mg}$ of chloramphenicol/ml of solution, and $24 \mathrm{~h}$ later Hoagland solution containing nitrate was added to all the seedlings (with or without chloramphenicol, as indicated in the table), and one set of the seedlings grown in the dark was immediately transferred to light (designated as 'darklight'). Fresh solutions were provided after every $12 \mathrm{~h}$. The enzyme activities in the shoot system of seedlings were determined after $28 \mathrm{~h}$. Nitrate reductase and nitrite reductase activities in the control seedlings were 1.44 and 11.20 units respectively.

\section{Treatment}

Continuous light (control)

Continuous light + chloramphenicol

Dark-light

Dark + chloramphenicol-light

Dark

Dark + chloramphenicol
Activity ( $\%$ of control)

$\begin{array}{cc}\text { Nitrate reductase } & \text { Nitrite reductase } \\ 100 & 100 \\ 60.5 & 12.1 \\ 69.5 & 91.6 \\ 10.5 & 15.5 \\ 2.9 & 0 \\ 2.1 & 0\end{array}$


Table 2. Influence of inhibitors of the Hill reaction on induction of nitrate reductase and nitrite reductase in the shoot system of rice seedlings

At 16 days after germination, rice seedlings grown in plastic pots in the light were sprayed at intervals of $12 \mathrm{~h}$ with solutions of the inhibitors prepared in $0.1 \%$ Tween. The control seedlings were sprayed with a solution of $0.1 \%$ Tween alone. At $24 \mathrm{~h}$ after the first spray Hoagland solution containing nitrate was added to the seedlings, and $24 \mathrm{~h}$ later nitrate reductase and nitrite reductase activities in the shoot system and Hill activity in the isolated chloroplasts were determined as outlined in the Materials and Methods section. Nitrate reductase and nitrite reductase activities in the control seedlings were 2.30 and 13.60 units respectively, and Hill activity was $1.19 \mu \mathrm{mol}$ of dichlorophenol-indophenol reduced $/ 5 \mathrm{~min}$ per $\mathrm{mg}$ of chlorophyll.

Treatment

Control

Simazin

3-(3,4-Dichlorophenyl)-1,1-dimethylurea
Concn. of inhibitor $(\mu \mathrm{g} / \mathrm{ml})$

$-\overline{0.25}$
0.50
1.00
0.50
1.00
5.00

Activity (\% of control)

$\begin{array}{ccc}\begin{array}{c}\text { Nitrate } \\ \text { reductase }\end{array} & \begin{array}{c}\text { Nitrite } \\ \text { reductase }\end{array} & \begin{array}{c}\text { Hill } \\ \text { activit }\end{array} \\ 100 & 100 & 100 \\ 139 & 100 & 80.9 \\ 103 & 96 & 74.6 \\ 81 & 53 & 67.3 \\ 81 & 59 & 79.4 \\ 54 & 49 & 64.5 \\ 9 & 29 & 25.3\end{array}$

Table 3. Nitrate reductase and nitrite reductase activities in the covered and illuminated regions of partially exposed leaves

Rice seedlings were grown in plastic pots in continuous light and after 15 days, the lower half of some of the leaves was covered with a black paper and at the same time one set of seedlings was transferred to darkness. After 4 days the seedlings were provided with nutrient solution containing nitrate, and $24 \mathrm{~h}$ later the enzyme activities in the lower and upper half portions of the leaves were determined separately.

Units of enzyme activity

Treatment

Whole seedling exposed Upper half

Lower half

Lower half of leaves covered

Upper half

Lower half

Seedlings in dark

$\overbrace{\text { Nitrate reductase }}^{\text {Nitrite reductase }}$

2.00

19.11

2.53

14.00

2.74

0.32

0.05

24.80

1.70

1.10 the cellophan filters was adjusted so as to obtain $40 \%$ transmission of the wavelength of light having least absorption in the filters, Seedlings were grown in sunlight filtered through these papers. It was observed that green light was least efficient for synthesis of nitrate reductase in green seedlings. In etiolated seedlings exposed to the same treatments, orange and red light was much more efficient for synthesis of both nitrate reductase and nitrite reductase. Since longer wavelengths of visible light have been reported to be more effective in chlorophyll synthesis (Koski et al., 1951; Withrow et al., 1953), these might be indirectly stimulating the synthesis of nitrate re- ductase and nitrite reductase by contributing towards a more rapid development of photosynthetic apparatus than the light of shorter wavelengths. It is however desirable to use more precise monochromatic filters to confirm these qualitative results.

\section{Partial exposure of leaves}

In the same leaf, the portion exposed to light had severalfold higher activities of both the enzymes compared with the segments covered with black paper (Table 3). Thus photosynthetic reactions taking place in the exposed part could not support induction of 


\section{Table 4. Effect of partial and complete removal of $\mathrm{CO}_{2}$ on synthesis of nitrate reductase and nitrite reductase}

For studying the effect of partial removal of $\mathrm{CO}_{2}, 15$-day-old rice seedlings grown in $100 \mathrm{ml}$ beakers in the light, were placed in flat plastic bowls with a $2.5 \mathrm{~cm}$-deep layer of $20 \%$ (w/v) KOH at the bottom. Beakers $(2$ litres capacity) were inverted over the seedlings with their edges dipped in $\mathrm{KOH}$ solution. With the control seedlings an equal volume of water was placed in the plastic bowls instead of $\mathrm{KOH}$. After $36 \mathrm{~h}$ the seedlings were supplied with Hoagland solution containing nitrate and in one of the sets of the seedlings the nutrient solution was supplemented with $2 \%(\mathrm{w} / \mathrm{v})$ sucrose. After these additions the air inside the beakers was rapidly flushed with $\mathrm{CO}_{2}$-free air for $10 \mathrm{~min}$. The enzyme activities were assayed $24 \mathrm{~h}$ later. The nitrate reductase and nitrite reductase activities of the control seedlings were 1.60 and 16.4 units respectively. The experimental conditions for examining the effect of complete removal of $\mathrm{CO}_{2}$ were as described above, except that the seedlings were kept in airtight chambers and continuously aerated with $\mathrm{CO}_{2}$-free air. In controls, atmospheric air was circulated through the chamber. An additional set of seedlings was transferred to darkness at the same time as the other seedlings were placed in the airtight chambers. The nitrate reductase and nitrite reductase activities of the control seedlings were 1.20 and 8.33 units respectively.

\begin{tabular}{|c|c|c|c|c|}
\hline \multirow[t]{2}{*}{ 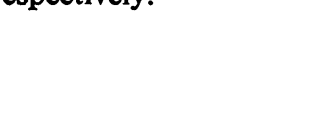 } & \multicolumn{4}{|c|}{ Activity ( $\%$ of control) } \\
\hline & \multicolumn{2}{|c|}{ Partial removal of $\mathrm{CO}_{2}$} & \multicolumn{2}{|c|}{ Complete removal of $\mathrm{CO}_{2}$} \\
\hline Treatment & $\begin{array}{l}\text { Nitrate } \\
\text { reductase }\end{array}$ & $\begin{array}{l}\text { Nitrite } \\
\text { reductase }\end{array}$ & $\begin{array}{l}\text { Nitrate } \\
\text { reductase }\end{array}$ & $\begin{array}{l}\text { Nitrite } \\
\text { reductase }\end{array}$ \\
\hline Control & 100 & 100 & 100 & 100 \\
\hline $\mathrm{CO}_{2}$-free atmosphere & 59 & 87 & 5.8 & 8.0 \\
\hline $\mathrm{CO}_{2}$-free $+2 \%$ sucrose & 53 & 76 & 9.1 & 8.0 \\
\hline Transferred to dark & - & - & 9.1 & 8.0 \\
\hline
\end{tabular}

Table 5. Effect of light on the synthesis of nitrate reductase and nitrite reductase in rice seedlings developed from excised embryos

Embryos of the sterilized rice seeds soaked for $24 \mathrm{~h}$ in water were gently removed and cultured on White's synthetic media containing different concentrations of sucrose. One set of the tubes was kept in complete darkness and the other in an illuminated chamber. After 11 days activities of nitrate reductase and nitrite reductase were determined.

\begin{tabular}{lccc}
\multirow{2}{*}{ Light } & $\begin{array}{c}\text { Concn. of sucrose } \\
\text { in media } \\
(\%, w / v)\end{array}$ & $\overbrace{\text { Nitrate reductase }}$ & Nitrite reductase \\
\multirow{2}{*}{ Dark } & 2 & 3.06 & 17.00 \\
& 4 & 1.75 & 19.91 \\
& 2 & 0.03 & 1.06 \\
& 4 & 0.03 & 1.04
\end{tabular}

enzymes in the covered area of the same leaf. This experiment ruled out the possibility that any translocatable factors such as early products of photosynthesis could replace the light effect.

\section{Role of $\mathrm{CO}_{2}$}

When $\mathrm{CO}_{2}$ was absorbed (with $\mathrm{KOH}$ ) from the atmosphere in which the seeds were germinating a partial removal of the $\mathrm{CO}_{2}$ generated by respiration was accomplished. Under these conditions synthesis of nitrate reductase and nitrite reductase was inhibited to the extent of $40 \%$ and $13 \%$ respectively
(Table 4). When $\mathrm{CO}_{2}$ was more vigorously eliminated by continuous passage of $\mathrm{CO}_{2}$-free air about $90 \%$ inhibition of both the enzymes was observed. In these experiments sucrose could not replace $\mathrm{CO}_{2}$ for the synthesis of the enzymes in light.

\section{Synthesis of enzymes in excised embryo}

In excised embryos, cultured on a synthetic medium containing $2 \%(\mathrm{w} / \mathrm{v})$ sucrose for 12 days, negligible synthesis of these enzymes was observed in the dark (Table 5). In cultures grown in the light substantial synthesis of both the enzymes occurred, 
but doubling the sucrose concentration decreased nitrate reductase synthesis by $50 \%$. Nitrite reductase synthesis was not affected by various sucrose concentrations in the light.

\section{Discussion}

The results clearly demonstrate that like that of nitrate reductase, the synthesis of nitrite reductase is also influenced by light. In most of the experiments both the enzymes were affected to the same extent by treatments that interfere with reactions of photosynthesis. Thus in green plants synthesis of the enzymes commenced as soon as nitrate was supplied in the light (Fig. 1), whereas in etiolated seedlings a time-lag of about $2-3 \mathrm{~h}$ was essential after illumination (Fig. 2), during which time the synthesis of photosynthetic apparatus occurred. Again nitrite reductase was more sensitive to chloramphenicol treatment than nitrate reductase in green tissues, but when the antibiotic was added to the etiolated seedlings, on subsequent exposure to light, inhibition of both the enzymes was the same, i.e. $85 \%$. The latter treatment is known to interfere with the development of chloroplasts (Kirk, 1970). Experiments with cycloheximide (Figs. 3 and 4) showed that fresh protein synthesis in light is necessary for the formation of active enzymes. Inactive enzymes or precursors were not formed in the dark even when nitrate was present. Thus the effect of light could not be due to activation of an inactive precursor synthesized in the dark.

The strict requirement of $\mathrm{CO}_{2}$ for the synthesis of enzymes in light poses a problem: whether the lightreactions of photosynthesis per se have any direct role in the induction process or whether very early products of carbon assimilation, formed in the dark reaction of photosynthesis, are involved. Our results, as well as those of Kanangara \& Woolhouse (1967) show that sucrose supplied exogenously cannot replace $\mathrm{CO}_{2}$ for synthesis of enzymes in the light. In excised-embryo cultures the sugar supplied in the dark could not eliminate the requirement for light. Moreover, experiments with partial exposure of leaves showed that early products of photosynthesis, which were likely to be translocated from the illuminated regions of the leaf to the root system, were apparently not effective in the synthesis of the enzymes in the lower covered half of the same leaf. While discussing the stimulatory effect of $\mathrm{CO}_{2}$ on nitrate assimilation in green algae, Grant \& Turner (1969) have implied that carbon compounds formed only in the Calvin cycle are used to assimilate nitrate into cell nitrogen. They have not, however, studied the role of $\mathrm{CO}_{2}$ in the synthesis of the enzymes, but have suggested that the control mechanism might operate either at the level of nitrate reductase and nitrite reductase or, as indicated by Warburg \& Negelein (1920), at the level of absorption of anions. The latter suggestion can, however, be eliminated in rice seedlings by the results of partial exposure of the leaf to light. It is obvious that anions absorbed through the roots have to pass through the covered lower half region of the leaf to the upper illuminated part. Thus non-availability of the inducer cannot be a factor for the diminished synthesis of enzyme in the dark portion of the leaf.

The report that gibberellin and kinetin supplied to tobacco leaves in the dark can replace the light requirement does not appear to be applicable to our results. Both these growth regulators can be synthesized in the roots and transported to aerial parts of the plants and are also easily diffusible (Lang, 1970; Phillips, 1971). They would thus be expected to be available in parts of the same leaf covered with black paper. It is also not certain whether $\mathrm{CO}_{2}$ deprivation or inhibition of the Hill reaction by specific chemicals such as 3-(3,4-dichlorophenyl)-1,1dimethylurea and simazin would seriously impede synthesis and supply of these hormones. Travis et al. (1970a) and Travis \& Key (1971) have explained the effect of light on the basis of the close correlation between content of polyribosomes and synthesis of nitrate reductase. In etiolated corn seedlings transferred to light, they found a continuous increase in nitrate reductase activity as well as in the polyribosome content of the leaves. According to them, ATP formed during photosynthesis is necessary for the maintenance of integrity of cytoplasmic polyribosomes required for protein synthesis. These authors have suggested that in darkness the required energy could be supplied by respiratory oxidative phosphorylation, thus indicating that the effect of light might not be specific. Although they observed enzyme synthesis in green-leaf disc kept in darkness, this effect could very well be a manifestation of the residual effect of prior light treatment. Our results, however, indicate that when non-cyclic electron flow is blocked but cyclic photophosphorylation is taking place, the synthesis of both the enzymes is still decreased. This is clear from experiments where Hill activity is inhibited by specific chemicals (Table 2) or by complete $\mathrm{CO}_{2}$ deprivation (Table 4). It would, however, be expected that under these conditions cyclic photophosphorylation could provide ATP for maintenance of integrity of polyribosomes. According to Ramirez et al. (1968), protein synthesis in isolated chloroplasts is driven by ATP formed by cyclic photophosphorylation and is not affected by inhibitors of non-cyclic reactions such as 3-(3,4-dichlorophenyl)-1,1-dimethylurea. However, no stimulation was found by the addition of sucrose either to seedlings maintained in a $\mathrm{CO}_{2}$-free atmosphere or to excised embryo culture, although in both cases respiratory metabolism would be expected to generate the additional ATP supposed to be needed. All these results suggest a direct role of

Vol. 130 
light, which could not be replaced by ATP generated by pathways other than non-cyclic electron flow. Thus light may be playing a role in the synthesis of the enzyme through the Hill reaction. The work of Warburg \& Krippahl (1960), demonstrating a strict requirement of $\mathrm{CO}_{2}$ for the Hill reaction, was confirmed by Good (1963) and by Batra \& Jagendorf (1965). Our results show that vigorous elimination of $\mathrm{CO}_{2}$ almost completely blocked the synthesis of these enzymes. In other experiments a relationship between inhibition of the Hill reaction and synthesis of the enzymes was observed. The only exception was simazin at low concentration, which stimulated nitrate reductase synthesis in spite of inhibition of the Hill activity. No satisfactory explanation can be offered for this anomaly, since the exact mechanism by which simazin inhibits photosystem II is not known. However, at high concentrations simazin showed the same effect as 3-(3,4-dichlorophenyl)-1,1-dimethylurea. Increase in activity of several other enzymes such as transaminase, $\alpha$-amylase, starch phosphorylase, adenosine triphosphatase (Singh \& Salunkhe, 1970), $\delta$-aminolaevulinate dehydratase (Wu et al., 1971a), pyruvate kinase, cytochrome oxidase and glutamate dehydrogenase (Wu et al., 1971b) as a result of application of simazin at sub-lethal concentrations has also been observed.

Persistence of a small residual effect for a short time after transfer of plants to darkness (Fig. 1) suggests that conditions favourable for the enzyme synthesis have already been created by prior light exposure. It is likely that redox changes taking place in the tissue as a result of the Hill reaction are involved in the induction process. It is known that in facultative anaerobic bacteria, such as the denitrifiers, nitrate reductase is stimulated by decreased $\mathrm{O}_{2}$ partial pressure (Fewson \& Nicholas, 1961). In a similar manner formation of Hill reductants in the light might alter the internal redox state of green tissues leading to the synthesis of the enzymes. The observation of Sawhney et al. (1972) that in chlorophyll mutants of barley, nitrate reductase activity was negligible in albino leaves but quite high in green leaves of the same plant supports this view. Small but significant nitrite reductase activity was, however, present in albino leaves, although our present results show that nitrate reductase and nitrite reductase activities are both controlled by light to almost the same extent.

S. K. S. is grateful to the Rockefeller Foundation for the award of a part-time assistantship.

\section{References}

Arnon, D. I. (1949) Plant Physiol. 24, 1

Batra, P. P. \& Jagendorf, A. T. (1965) Plant Physiol. 40, 1074
Beevers, L. D., Peterson, D. M., Shannon, J. C. \& Hageman, R. H. (1963) Plant Physiol. 38, 675

Beevers, L., Schrader, L. E., Flesher, D. \& Hageman, R. H. (1965) Plant Physiol. 40, 691

Bishop, N. I. (1962) Biochim. Biophys. Acta 57, 186

Boulter, D. (1970) Annu. Rev. Plant Physiol. 21, 91

Chen, T. M. \& Ries, S. K. (1969) Can. J. Bot. 47, 341

Fewson, C. A. \& Nicholas, D. J. D. (1961) Nature (London) 190, 2

Gibbons, G. C., Raison, J. K. \& Smillie, R. M. (1969) Proc. Aust. Biochem. Soc. 2, 43

Glasziou, K. T. (1969) Annu. Rev. Plant Physiol. 20, 63

Good, N. E. (1963) Plant Physiol. 38, 298

Gorham, P. R. (1955) Methods Enzymol. 1, 22

Grant, B. R. \& Turner, I. M. (1969) Comp. Biochem. Physiol. 29, 995

Hageman, R. H. \& Flesher, D. (1960) Plant Physiol. 35, 700

Hewitt, E. J. (1952) Commonw. Bur. Hort. Plant Crops (G. Brit.), Tech. Commun. no. 2

Joy, K. W. \& Hageman, R. H. (1966) Biochem. J. 100, 263

Kanangara, C. G. \& Woolhouse, H. W. (1967) New Phytol. 66, 553

Kirk, J. T. O. (1970) Annu. Rev. Plant Physiol. 21, 11

Koski, V. M., French, C. S. \& Smith, J. H. C. (1951) Arch. Biochem. Biophys. 31, 1

Lang, A. (1970) Annu. Rev. Plant Physiol. 21, 537

Lips, S. H. \& Roth-Bejerano, N. (1969) Science 166, 109

Lowry, O. H., Rosebrough, N. J., Farr, A. L. \& Randall, R. J. (1951) J. Biol. Chem. 193, 265

Phillips, I. D. J. (1971) Introduction to Biochemistry and Physiology of Plant Growth Hormones, p. 28, McGrawHill, New York

Ramirez, K. M., del Campo, F. F., Paneque, A. \& Losada, M. (1966) Biochim. Biophys. Acta 118, 58

Ramirez, J. M., del Campo, F. F. \& Arnon, D. I. (1968) Proc. Nat. Acad. Sci. U.S. 59, 606

Ries, S. K., Chmiel, H., Dilley, D. R. \& Filner, P. (1967) Proc. Nat. Acad. Sci. U.S. 58, 526

Roth-Bejerano, N. \& Lips, S. H. (1970) New Phytol. 69, 165

Sawhney, S. K. \& Naik, M. S. (1972) Biochem. J. 128, 23 P

Sawhney, S. K., Ved Prakash \& Naik, M. S. (1972) FEBS Lett. 22, 200

Schrader, L. E., Beevers, L. \& Hageman, R. H. (1967) Biochem. Biophys. Res. Commun. 26, 14

Schrader, L. E., Ritenour, G. L., Eilrich, G. L. \& Hageman, R. H. (1968) Plant Physiol. 43, 930

Shibata, M., Kobayashi, M. \& Takahashi, E. (1969) Plant Cell Physiol. 10, 337

Singh, B. \& Salunkhe, D. K. (1970) Can.J. Bot. 48, 2213

Smillie, R. M., Graham, D., Dwyer, M. R., Grieve, A. \& Tobin, N. F. (1967) Biochem. Biophys. Res. Commun. 28, 604

Street, H. E. \& Henshaw, G. G. (1966) in Cells and Tissues in Culture: Methods, Biology and Physiology (Willmer, E. N., ed.), vol. 3, p. 459, Academic Press, London

Travis, R. L. \& Key, J. L. (1971) Plant Physiol. 48, 617

Travis, R. L., Huffaker, R. C. \& Key, J. L. (1970a) Plant Physiol. 46, 800

Travis, R. L., Jordan, W. R. \& Huffaker, R. C. (1970b) Physiol. Plant 23, 678 
Tweedy, J. A. \& Ries, S. K. (1967) Plant Physiol. 42, 280

Vishniac, W. (1957) Methods Enzymol. 4, 342

Warburg, O. \& Krippahl, G. (1960) Z. Naturforsch. B 15, 367

Warburg, O. \& Negelein, E. (1920) Biochem. Z. 110, 66
Withrow, R. B., Klein, W. H., Price, L. \& Elstad, V. (1953) Plant Physiol. 28, 1

Wu, M. T., Singh, B. \& Salunkhe, D. K. (1971a) Phytochemistry 10, 2025

Wu, M. T., Singh, B. \& Salunkhe, D. K. (1971b) Plant Physiol. 48, 517 